\title{
COMPARISON OF E-LEARNING WITH STANDARD ATTENDANCE TEACHING AT TECHNICAL UNIVERSITY
}

\author{
Lenka HRUŠKOVA, Vysoká škola technická a ekonomická v Českých \\ Budějovicích
}

Přijato: 17. 4. 2016 / Akceptováno: 2. 8. 2016

Typ článku: Výzkumná studie

DOI: $10.5507 /$ jtie.2016.027

Abstract: Summary: The study examines the successfulness of e-learning in university education compared to standard full-time classes. The objective of the article is to contribute to the current discussion on the significance and evaluation of digital technologies in the university students studies. Through an empirical research it seeks the answer to the question whether it is more appropriate to use e-learning or standard full-time classes for students of a bachelor's degree programme in the teaching of specialized subjects in a foreign language, whether e-learning is equally successful for males and females in the teaching of specialized subjects in a foreign language or whether there is a correlation between e-learning and fields of studies.

Key words: e-learning, traditional teaching, specialized language, gender, technical, economic study programs

\section{KOMPARACE E-LEARNINGU SE STANDARDNÍ PREZENČNÍ VÝUKOU NA TECHNICKÉ VYSOKÉ ŠKOLE}

Resumé: Studie se věnuje úspěšnosti e-learningu ve vysokoškolském vzdělávání vzhledem ke standardní prezenční výuce. Cílem článku je přispět $k$ současné diskusi o významu a hodnocení digitálnich technologií ve studiu vysokoškolských studentů. Prostřednictvím empirického šetřeni hledá odpověd' na otázku, zdali je vhodnějši u studentu bakalářského studia užit v odborné cizojazyčné výuce e-learning nebo standardní prezenční výuku, zda je e-learning v odborné cizojazyčné výuce stejně úspěšný pro muže $i$ ženy nebo jestli existuje korelace mezi e-learningem a studijními obory.

Klíčová slova: e-learning, standardní prezenční výuka, odborný jazyk, gender, technické, ekonomické studijní programy

*Autor pro korespondenci: hruskova@ mail.vstecb.cz 


\section{1 Úvod}

V poslední době se často mluví o různých formách interaktivního vzdělávání, o využití informačních a komunikačních technologií (ITC) ve vzdělávání. Informační a komunikační technologie přinášejí mnoho pozitivních efektů, které vhodným způsobem doplňují a podporují vzdělávání. Některé formy studia v rámci terciárního vzdělávání jsou dokonce na použití těchto technologií založeny.

Primárně je třeba však konstatovat, že k pochopení problémů výuky opírající se o e learning či některé jeho novější formy (blended-learning, m-learning) je třeba nejprve pochopit základní pojem. Klíčovým pojmem naší studie je pojem e-learning. Evropská unie (2009, s. 13) definuje e-learning jako: „... evropský program na poli informačních technologií (ICT) zabývající se vyučováním a tréninkem, který podporuje začlenění ICT do všech učebních systémů a prostředí (formálních, neformálních, školních, vysokoškolských a tréninkových).“ Evropská definice má na e-learning široký pohled, což je její největší slabina. Specifikuje jen velmi málo z toho, co nám ICT a e-learning při vyučování nabízí. Ve zprávě z výzkumu vedeného OECD se zdůražnuje, že e-learning je zvláště důležitý pro rozvoj a/nebo podporu terciárního vzdělávání, zvyšuje kvalitu vzdělávání a zároveň snižuje cenu vzdělávání jak pro studenty, tak pro jeho poskytovatele (E-learning in Tertiary Education 2005, str. 21). Žádoucí cílový stav uplatňování e-learningu pak Květoň $(2003$, s. 4) vyjadřuje jako „takovou integraci e-learningu do vzdělávání, která zvýší př́stup ke vzdělávání a zajistí vyhovující kvalitu vzdělávání za přijatelnou cenu“. Zároveň však zdůrazňuje fakt, že ve vyspělých zemích se e-learning použivá především pro zvýšení počtu celoživotně se vzdělávajících dospělých studujících.

Z mnoha definic termínu e-learning (Klement, 2015; Zounek a Sudický, 2012; Hubáček, 2013; Barešová, 2011; Kopecký, 2006; Zounek, 2009; Wagner, 2009; Pejsar, 2007; Vaněk, 2008; Clark, 2003; Nocar, 2004) budeme pro naše účely používat tento pojem jako komplexní počítačovou (elektronickou) podporu vzdělávání, čímž budeme akcentovat fakt, že za e-learning považujeme pouze takovou počítačovou podporu vzdělávání, kde je komunikace s počítačem (nebo s člověkem - tutorem či spolužákem ale prostřednictvím počítače), skutečně hlavním nástrojem vzdělávání.

$\mathrm{S}$ rozsáhlým rozvojem e-learningu $\mathrm{v}$ Evropě je značná pozornost věnována jeho evaluaci. Za zmínku stojí výzkumný projekt programu Leonardo da Vinci s názvem Thematic monitoring (Attwell, 2006). Z jeho závěrů vyplývá, že pro úspěšnost e-learningu, nesmí být v budoucnosti prioritou rozvoj e-learningových technologií a platforem (typu LMS, WBT), ale vývoj a zlepšování procesů ř́zeného sebeučení (např. intelligent learning processes), zlepšování kvality vědomostní báze (učební texty, multimedializace, interakce) a využití př́stupů konstruktivismu. Do popředí by se tedy měly dostat didaktické aspekty e-learningu týkající se zejména profesionálního řízení samostudia, kolaborativních forem práce a kvalitně zpracovaných studijních opor tak, jak to ukazují některé studie.

Kvalita a povaha komunikace $\mathrm{v}$ angličtině $\mathrm{u}$ vysokoškolských studentů byla zkoumána v několika studiích:

1. Warschauer (1995) ve své studii došel ke zjištění, že v elektronickém prostředí se snižuje dominance některých jedinců při diskusi, že se různě aktivní studenti zapojují rovnoměrněji do komunikace, a že jazyk používaný $\mathrm{v}$ elektronickém prostředí je normálnější a komplexnější. 
2. Fernandez (2002) ve své studii popisuje a analyzuje vytvoření výukového prostředí na internetu pro univerzitní studenty oboru stavebnictví, kde jsou studentům nabízeny internetové adresy odborně zaměřených webových míst $v$ angličtině. Sami studenti si volí internetové odkazy tak, aby to odpovídalo jejich stylu učení. Studie poukazuje na potenciál internetu pro rozvoj studijní autonomie a zároveň možnost zvládnout značné množství materiálu na internetu.

Diskuse o kvalitě e-learningu z hlediska jeho potenciálního př́ínosu pro studujícího jsou aktuální nejen v ČR. V současnosti se ve světě velmi živě diskutuje o e-learningu zejména v souvislosti s nabídkou vysokoškolského vzdělávání a úvahami o vyšší nebo naopak nižší kvalitě e-learnigových studijních programů při srovnání se standardní prezenční formou studia. Zde nabízíme několik různých výstupů:

1. Ve svých výzkumných závěrech opírajících se o šetření Zhao $(2002,3)$ a Yeung (2002) zdůrazňují zejména chybějící možnost fyzického kontaktu učitele a studenta. Upozorňují na nebezpečí technických problémů nebo nedostatečného technologického vybavení a dovedností potenciálních zájemců o studijní obsah. Tito skeptici e-learningu operují s tradičním názorem, že tato forma vzdělávání nedosahuje na svém výstupu stejné kvality.

2. Př́kladem komparací výsledků e-learningu se standardní prezenční výukou může být výzkum provedený na fakultě informatiky a managementu Univerzity Hradec Králové, kde v letech 2003/2004, 2004/2005 a 2005/2006 probíhalo testování vědomostí studentů v predmětu Odborná angličtina. Výsledky standardizovaného testování prokázaly, že „při pedagogicky správném vytvoření a vedení e-kurzu je možné distanční formou dosáhnout stejných studijních výsledků, navíc v podmínkách, které vyhovují a odpovídají technickým, společenským a ekonomickým požadavkům současné doby a požadavkům na vzdělávání“ (Šimonová, 2008).

V rámci grantu MPSV ČSR bylo realizováno šest empirických výzkumů v letech 2005-2006 (Sak a Saková 2007). Jednalo se v prvém př́ípadě o reprezentativní výzkum české populace starší patnácti let „Komputerizace společnosti, vzdělávání a životní styl“. Výběrový soubor obsahoval 1818 respondentů. Druhý výzkum „E-learning - učitelé“, realizovaný koncem roku 2006 jako anketa, tvořilo 170 učitelů všech vzdělávacích stupňù. Navazující výzkum „E-learning experti“ tvořilo 27 expertů, kteří se zabývají profesionálně e-learningem. V listopadu a prosinci 2005 se uskutečnil kvantitativní výzkum „Časové rozpočty české populace“. Výběrový soubor zahrnoval 754 časových snímků. Rovněž se ukázalo, že využívání e-learningu, jak odpovídali experti a učitelé, je $\mathrm{v}$ př́mé souvislosti $\mathrm{s}$ formou a stupněm vzdělávání.

Frekventovanou oblastí zájmu je korelace pohlaví a elektronického vzdělávání. Touto problematikou se zabývali např. Yukselturk a Bulut (2009). Výzkum zahrnoval 145 účastníků online kurzu, založeném na synchronních a asynchronních komunikačních metodách prostřednictvím internetu. Zmínění autoři Yukselturk a Bulut (2009) potvrdili, že testová úzkost ovlivňuje výsledky žen; u mužů hrály důležitou roli faktory jako hodnota úkolu a důvěra ve vlastní učení a osobně vnímaná zdatnost. Statisticky výrazné odchylky nebyly potvrzeny u vnitřní a vnější cílové orientace. 


\section{Cíl práce}

Záměrem bylo provést aplikovaný výzkum na Vysoké škole technické a ekonomické v Českých Budějovicích (VŠTE). Výzkumné šetření bylo zacíleno na komparaci evaluace úspěšnosti e-learningu a standardní prezenční výuky $\mathrm{v}$ utváření odborných jazykových vědomostí v závislosti na konkrétních proměnných. Standardní prezenční výuka je základním typem studia na VŠTE, které navazuje na středoškolské vzdělání. Výuka probíhá formou pravidelných přednášek a cvičení /“face to face“/. Výuka probíhá dle organizace akademického roku a student je povinen účastnit se většinového počtu hodin výuky (viz Studijní a zkušební řád VŠTE).

Jako proměnné byly definovány studijní obor /technický, ekonomický/ a gender. Na základě cíle byly stanoveny výzkumné otázky:

Je pro daný soubor vysokoškoláků bakalářského studia vhodnější užít v odborné cizojazyčné výuce e-learning nebo standardní prezenční výuku? Je e-learning vhodnější pro studenty technických bakalářských oborů, než pro studenty ekonomických studijních oborů? Jaký je vztah mezi e-learningem a genderem?

\section{Použité výzkumné metody}

Zjišt'ování úspěšnosti e-learningu bylo provedeno pomocí experimentu, který probíhal od akademického roku 2011/2012 a ukončen byl v roce 2013/2014. Komparace úspěšnosti e-learningu se standardní prezenční výukou v odborném cizím jazyce (úroveň odborných cizojazyčných dovednosti a znalosti) byla zjišt'ována pomocí opakovaných elektronických kvazistandardizovaných jazykových didaktických testů a ústní prezentace (viz link NEP_1 -

https://is.vstecb.cz/auth/el/5610/leto2014/NEP_1/odp/NEP1_29_5_8_00_D215_Lejsko va.qref?info)

Jednalo se o sumativní hodnocení na konci každého semestru (dle doporučených studijních plánů ve třetím a čtvrtém semestru; popřípadě v pátém semestru). Jazykové testování na VŠTE se standardně provádí u veškeré jazykové výuky několik let již pouze elektronicky. Semestrální testování zajišt'ují garanti předmětů; vyhodnocování probíhá automaticky v Informačním systému VŠTE v Českých Budějovicích.

V rámci experimentálního postupu, výzkumné metody, která spočívá v možnosti manipulování s proměnnými, aby mohly býti odhaleny hlubší kauzální souvislosti, jsme použili různorodé metody sběru údajů (e-testy, standardizovaný dotazník, rozhovor). Jednalo se tedy o výzkumnou metodu, která synteticky využila možnosti ostatních výzkumných metod. Jako nezávisle proměnná zde vystupuje e-learning; jako závisle proměnnou považujeme výsledky v semestrálních testech a ústní prezentaci studentů.

\section{Průběh a výsledky výzkumu}

\section{1 Popis výzkumného vzorku}

Subjekty experimentu byli studenti bakalářského studia veřejné vysoké školy z ekonomických a technických studijních programů. Byl proveden stratifikovaný výběr, který spočíval ve vytvoření zaměřených skupin - strat -, do kterých byli zařazeni studenti příslušného studijního oboru a ročníku. Výzkumné šetření bylo založeno na koncepci experimentální a kontrolní skupiny. Tento přistup je analyzován v odborných pramenech, 
např. u Pelikána (1998), Gavory (2000), Kerlingera (1972), Chrásky (2007) a Hendricha (1988). Komparace dvou výukových metod je založena na ideji, že jedna skupina studentů je vyučována primárně jednou výukovou metodou, druhá skupina studentů odlišnou metodou.

Experimentální skupina, studenti, kteří studovali odbornou jazykovou výuku elearningem, čítala 148 studentů ( $\mathrm{n}=\mathrm{F}$ 105/M 43), kontrolní skupina, studenti, kteř́ studovali standardní prezenční výukou cizí jazyky, čítala 335 studentů (n = F 178/M 157): EKO (186 osob ve standardní prezenční výuce a 91 osob v e-learningu); TECH (149 osob ve standardní výuce a 57osob v e-learningu).

Pro zápis do výše zmíněných předmětů byl prerekvizitou platný certifikát na deskriptoru B1 SERR pro jazyky, který zaručoval, že všichni studenti ovládaji cizí jazyk na stejném stupni Společného evropského rámce pro jazyky (SERR). Z tohoto důvodu nebylo nutné realizovat pretest.

\begin{tabular}{|c|c|c|c|}
\hline & Certifikát B1 SERR & působení & posttest \\
\hline skupina A & ano & P1 & ano \\
\hline skupina B & ano & P2 & ano \\
\hline
\end{tabular}

Pozn."“ano" ve schématu znamená, že se dané měření uskutečnilo, že certifikát vlastní

\section{Tab. č. 1: Experimentální plán}

\section{Výuka v experimentální skupině}

Výuka odborně zaměřeného cizího jazyka začala pro studenty z této skupiny stejně, jako pro studenty z kontrolní skupiny, ve druhém ročníku dle platných doporučených plánů $\mathrm{v}$ třetím semestru. Subjektům experimentální skupiny byla $\mathrm{v}$ průběhu šetření zadávána studijní témata, úlohy, zadání, které řešili primárně samostudiem z dostupných elektronických materiálů $\mathrm{v}$ informačním systému (IS) VŠTE a $\mathrm{z}$ dalších internetových stránek dle doporučení tutora či dle vlastního výběru. Na tutoriálech si studenti také vyměňovali adresy webových míst a cvičení či úlohy s klíči na daná témata, konzultovali nejasnosti v malých kooperujících skupinkách i individuálně s tutorem v cizím jazyce, využívali chat, cizojazyčnou e-mailovou komunikaci, poslechové odborné texty natočené rodilými mluvčími. Studentům bylo doporučeno soustředit se převážň na využití studijních e-learningových materiálů a on-line materiálů v IS. Elektronické stránky v IS se zaměřují na všechny čtyři řečové dovednosti: u poslechu a čtení poskytují elektronické moduly i výsledky a klíč či transkript textu pro poslech; produktivní řečovou dovednost mluvení (Speaking) „cvičili“ studenti na chatu, na videokonferencích či při konzultacích a semináŕích v malých skupinách.

\section{Výuka v kontrolní skupině}

Výuka odborného cizího jazyka (CJ) byla zahájena stejně jako pro studenty z experimentální skupiny, tedy ve druhém ročníku (třetím semestru) a trvala dva semestry. Studenti kontrolní skupiny ve standardní prezenční výuce se učili totožná odborná témata jako studenti v experimentální skupině. Výuka se opírala o komplexní výukové metody (Maňák, Švec, 2003). Byla uplatňována primárně skupinová a kooperativní jazyková výuka, projektová odborně zaměřená jazyková výuka a brainstorming. 
Cílem vysokoškolského odborného jazykového vzdělávání na VŠTE v bakalářských studijních programech $\mathrm{v}$ kontrolní skupině bylo, stejně jako v experimentální skupině, dosáhnout komplexních odborných znalostí a dovedností v daném cizím jazyku na deskriptoru B1 SERR pro jazyky.

\section{2 Výsledky - statistické zpracování dat}

V této kapitole se budeme zabývat řešením výzkumu opírajícím se o statistické zpracování dat. Pro vypočtení potřebných charakteristik byla provedena komparace, která naznačuje existenci vztahů. Použity byly statistické metody, které vyjadřují významnost rozdílu mezi údaji (Studentův t-test, ANOVA), korelační koeficient, faktorová analýza, směrodatná odchylka či analýza rozptylu. Používání e-learningu bylo v analýzách posuzováno jako nezávisle proměnná. Pro určení signifikance hypotézy byla použita hladina významnosti standardně ve shodě $\mathrm{s}$ územ $\mathrm{v}$ pedagogické metodologii vždy maximálně na $\mathrm{p}<0,05$ nebo $\mathrm{p}=0,05$.

\section{Použité zkratky:}

VSH - výběrová střední hodnota

VR - výběrový rozptyl

$\mathrm{RV}$ - rozsah výběru (tj. počet položek v daném výběru)

CJ - cizí jazyk

H0: Při e-learningu CJ je dosaženo stejného průměrného bodového hodnocení jako při standardní prezenční výuce CJ.

H1: Při e-learningu $C J$ je dosaženo různého průměrného bodového hodnocení než při standardní prezenční výuce $\mathrm{CJ}$.

\begin{tabular}{llll} 
Forma výuky & VSH & VR & RV \\
\hline e-learning & 78,78 & 20,37 & 150 \\
standardní p. výuka & 78,90 & 21,34 & 335 \\
\hline Celkem & 78,86 & 21,04 & 485
\end{tabular}

Tab. č. 2: Komparace standardní prezenční výuky s e-learningem

$\mathrm{Z}$ tabulky vidíme na první pohled dvě věci:

1. obě dvě skupiny (standardní prezenční výuka i e-learning) dosahují hodnocení skoro $79 \%$ a skupiny si jsou také velmi podobné (vidíme to $\mathrm{z}$ výběrové střední hodnoty)

2. podle výběrového rozptylu (VR) vidíme, že velká část studentů získala hodnocení mezi 65 a $95 \%$.

Nedokážeme říci, jaká část studentů dosahuje výsledky $\mathrm{v}$ tomto intervalu, ale dá se očekávat, že jenom statisticky málo významná část je mimo hodnoty tohoto intervalu. 


\begin{tabular}{|l|l|}
\hline Testovaná hodnota & 0,269 \\
\hline Dolní hranice kritického intervalu (normální rozdělení) & 1,960 \\
\hline p-hodnota (normální rozdělení) & $78,8 \%$ \\
\hline Dolní hranice kritického intervalu (Studentovo rozdělení) & 1,976 \\
\hline p-hodnota (Studentovo rozdělení) & $78,9 \%$ \\
\hline
\end{tabular}

Tab. č. 3: Přehled statistických hodnot pro testování H0 vs. H1

Současně byl proveden dvouvýběrový t-test: Vypočítali jsme testovací hodnotu (z údajů $\mathrm{v}$ tabulce), kterou jsme porovnali s kritickým intervalem - získaná data jsou výrazně pod hranicí, proto hypotézu H0 nezamítáme. Př́islušné hodnoty normálního rozdělení uvádíme jako aproximaci, nakolik jsou u rozsáhlých výběrů blízké hodnotám Studentova rozdělení.

H0: Při e-learningu $\mathrm{CJ}$ v technických oborech je dosaženo stejného průměrného bodového hodnocení jako při e-learningu CJ v ekonomických oborech: $\mu_{1}=\mu_{2}$.

$\mathrm{H}$ 2: Při e-learningu $\mathrm{CJ} \mathrm{v}$ technických oborech je dosaženo různého průměrného bodového hodnocení než při e-learningu CJ v ekonomických oborech: $\mu_{1}>\mu_{2}$.

\begin{tabular}{llll} 
Podle oborů & VSH & VR & RV \\
\hline e-learning & $\mathbf{7 8 , 7 8}$ & $\mathbf{2 0 , 3 7}$ & $\mathbf{1 5 0}$ \\
\hline ekonomické obory & 79,35 & 18,31 & 119 \\
technické obory & 76,56 & 22,11 & 31 \\
standardní p. výuka & $\mathbf{7 8 , 9 0}$ & $\mathbf{2 1 , 3 4}$ & $\mathbf{3 3 5}$ \\
\hline ekonomické obory & 78,65 & 14,36 & 186 \\
technické obory & 79,20 & 29,88 & 149 \\
\hline Celkový součet & $\mathbf{7 8 , 8 6}$ & $\mathbf{2 1 , 0 4}$ & $\mathbf{4 8 5}$
\end{tabular}

Tab. č. 4: Komparace hodnocení v technických a ekonomických oborech

Náhled do tabulky a grafu dává naději na prokázání statisticky významného rozdílu $v$ úspěšnosti studentů ekonomických a technických oborů (co se e-learningu týče). Skutečně je tomu tak; rozdíl je dokonce velmi významný, tj. p-hodnota testu vychází menší než 1\%. Zároveň je dobré poznamenat, že u standardní prezenční výuky mezi obory žádný významný rozdíl není. Velmi významný je (překvapivě) u studentů technických oborů rozdíl $\mathrm{v}$ úspěšnosti $\mathrm{v}$ závislosti na formě výuky: e-learning vede k statisticky významně horším výsledkům než standardní prezenční výuka. 


\begin{tabular}{|l|l|}
\hline Testovaná hodnota & 2,993 \\
\hline Dolní hranice kritického intervalu (normální rozdělení) & 1,960 \\
\hline p-hodnota (normální rozdělení) & $0,3 \%$ \\
\hline Dolní hranice kritického intervalu (Studentovo rozdělení) & 2,042 \\
\hline p-hodnota (Studentovo rozdělení) & $0,5 \%$ \\
\hline
\end{tabular}

Tab. č. 5: Přehled statistických hodnot pro testováni HO vs. H2.

K zamítnutí nulové hypotézy, že „při e-learningu CJ v technických oborech je dosaženo stejného průměrného bodového hodnocení jako při e-learningu $\mathrm{CJ} v$ ekonomických oborech: $\mu_{1}=\mu_{2}$ “, přispěly naměřené hodnoty; byly zjištěny významné rozdíly (hodnota pravděpodobnosti $p$ byla ve všech prŕípadech větší než 0,05 a signifikantnost rozdílů se prokázala).

Ekonomové vykazují při e-learningu velmi významně lepší výsledky než technici, přitom u standardní prezenční výuky tomu tak není. Stejně tak je velmi významný rozdíl u techniků mezi e-learningem a standardní prezenční výukou. Tento výsledek se ukazuje být stěžejním pro e-learning $\mathbf{C J}$.

Co se týká hodnocení úspěšnosti e-learningu vzhledem k pohlaví, musíme konstatovat, že gender je jednou z pravděpodobně nejčastěji zkoumaných proměnných působících individuální rozdíly v učení cizímu jazyku. Chápeme ho jako sociální konstrukt, pohlaví jako biologickou charakteristiku.

H0: Při e-learningu CJ u žen je dosaženo stejného průměrného bodového hodnocení jako při e-learningu $\mathrm{CJ} u$ respondentů mužského pohlaví: $\mu_{1}=\mu_{2}$.

H3: Při e-learningu CJ u žen je dosaženo různého průměrného bodového hodnocení než při e-learningu $\mathrm{CJ} u$ respondentů mužského pohlaví: $\mu_{1} \neq<\mu_{2}$.

\begin{tabular}{llll} 
Gender & VSH & VR & RV \\
\hline e-learning & $\mathbf{7 8 , 7 8}$ & $\mathbf{2 0 , 3 7}$ & $\mathbf{1 5 0}$ \\
\hline Muži & 78,14 & 19,53 & 41 \\
Ženy & 79,01 & 20,48 & 109
\end{tabular}

Tab. č. 6: Gender

Na základě statistického vyhodnocení jsme dospěli $\mathrm{k}$ závěru, že pro konkrétní výběrový soubor s 95\% spolehlivostí platí, že ženy dosahují stejných odborných jazykových znalostí z hlediska bodového hodnocení v závěrečných didaktických testech jako muži, a že studium prostřednictvím e-learningu je pro ženy stejně úspěšné jako pro muže. 


\begin{tabular}{|l|l|}
\hline Testovaná hodnota & 1,069 \\
\hline Dolní hranice kritického intervalu (normální rozdělení) & 1,960 \\
\hline p-hodnota (normální rozdělení) & $28,5 \%$ \\
\hline Dolní hranice kritického intervalu (Studentovo rozdělení) & 2,021 \\
\hline p-hodnota (Studentovo rozdělení) & $29,1 \%$ \\
\hline
\end{tabular}

Signifikantnost potvrzena nebyla.

\section{Tab. č. 7: Testovací statistika VO 3}

\section{Diskuze a závěry}

Na základě statistického vyhodnocení (viz výše) lze konstatovat, že pro konkrétní výběrový soubor s $95 \%$ spolehlivostí platí, že e-learning i standardní prezenční výuka vedou, z hlediska získaných odborných jazykových znalostí vyjádřených dosaženým počtem bodů $\mathrm{v}$ závěrečných didaktických hodnoceních, přibližně ke stejné úspěšnosti. Je žrejmé, že není možné jednoznačně určit úspěšnost e-learningu odborné cizojazyčné výuky. Hledané závislosti vyšly bud' statisticky nevýznamné, či dokonce mírně v neprospěch e-learningu cizího jazyka. Statistickým testováním nebyl zjištěn signifikantní rozdíl mezi standardní prezenční výukou a e-learningem. Naše údaje jsou v souladu s některými konkrétními výzkumnými studiemi, které přinášejí totožné důkazy. Např. ve svém článku Teaching courses online: a review of the research autoři ukazují, že výsledky e-learningového, online učení jsou srovnatelné se studijními výsledky při tradičních prezenčních kurzech (Talent-Runnels et. al. 2006).

Dle našeho mínění se e-learning CJ jeví jako jedna z možností, jež může být paralelní ke standardní prezenční výuce, avšak zdá se, že nebude plně saturovat pozitivní stránky standardní prezenční výuky. Z hlediska odborných cizojazyčných znalostí vykazovali studenti bakalářských oborů srovnatelné výstupy; nelze proto $\mathrm{v}$ tomto ohledu považovat e-learning ani za vhodnější, ani za méně vhodný (v komparaci se standardní prezenční výukou $\mathrm{CJ}$ ). Vhodná bude pravděpodobně kombinace obou metod $\mathrm{s}$ prrihlédnutím $\mathrm{k}$ osobnosti učitele, $\mathrm{k}$ osobnosti studentů, $\mathrm{k}$ jednotlivým výukovým hodinám (dopolední, odpolední hodiny; bloková výuka, atd.). Faktorů, které ovlivňují (ne)úspěšnost e-learningu v hodinách odborného cizího jazyka, je mnoho; některé byly pojmenovány, ale jejich výčet by byl daleko delší. Domníváme se, že je třeba využívat silné stránky e-learningu (e-learning na jednu stranu studenta vede v procesu učení, což je pozitivní aspekt, ale na druhou stranu mu nabízí relativně menší prostor pro jeho kreativitu, odlišný způsob myšlení a hledání vlastních cest) a eliminovat jeho slabší stránky. Najít vhodný poměr e-learningu a standardní prezenční výuky je, $\mathrm{v}$ dnešní přetechnizované době, nelehký úkol pro každého učitele.

Naše závěry se shodují např. se závěry Egera, které byly prezentovány v publikaci E-learning, evaluace e-learningu z prípadové studie z projektu Comenius (materiál je součástí projektu Socrates Comenius Virtual further education, s. 18). Shodně jako my autor konstatuje, že „nic nebrání tomu, aby pro řadu obsahů při použití různých forem a metod s využitím specifických prostředků byly dosaženy stejné cíle, jako u klasického vzdělávání.” Kombinace internetových zdrojů a učebních textů jako zdroje informací spolu s počítačem, který představuje pracovní nástroj studenta, je vhodným, ne-li př́ímo ideálním spojením pro některé studijní programy, potažmo předměty. Současné 
pedagogické metody kladou důraz na samostatnou práci a samostudium studentů, čímž dochází $\mathrm{k}$ podpoře autonomního a autoregulovaného učení. $\mathrm{V}$ tomto smyslu má ITC velký potenciál.

$\mathrm{Z}$ provedeného výzkumu současně vyplynulo, že $\mathrm{v}$ komparaci úspěšnosti u standardní prezenční výuky mezi obory žádný významný rozdíl není. Velmi významný rozdíl je ale u evaluace úspěšnosti v závislosti na formě výuky u technických oborů. E-learning vede $\mathrm{k}$ statisticky významně horším výsledkům než standardní prezenční výuka CJ. Zároveň ale ekonomové vykazují při e-learningu výrazně lepší výsledky než technici /viz Obrázek 1/. U standardní prezenční výuky CJ tomu tak není. Rozdíl je dokonce velmi významný, tj. p-hodnota testu vychází menší než $1 \%$. Tyto výsledky můžeme pokládat za stěžejní pro e-learning.

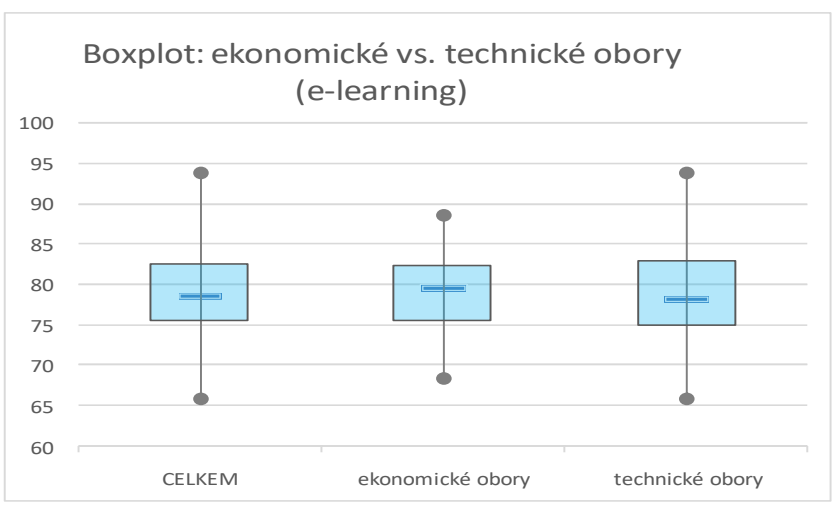

Obr. č. 1: Ekonomické vs. technické obory

Naše zjištění bylo překvapivé, nebot' jsme se domnívali, že studenti technických oborů, kteř́ jsou odchovaní počítači a internetem, budou vykazovat v e-learningu lepší výsledky, než ve standardní prezenční formě. To samé jsme předpokládali v komparaci s ekonomickým studijním oborem. Je ale možné, že odborná cizojazyčná výuka žádá u studentů technických studijních oborů více vysvětlení a osobního kontaktu s učitelem, než nabízí e-learning. Podobné závěry vyplynuly i ze studie (Liu, Moore, Graham, Lee 2003), kde bylo konstatováno, že by se měla výuka jazyka v počítačovém prostředí, tedy také na internetu, ř́dit obecně některými zásadními faktory, které musí být zohledněny i ve standardní prezenční výuce - především rozdíly mezi studenty a také specifiky typickými pro tato výuková prostředí. Podobné směřování ukázala i studie (Fernandez, 2001), která byly zaměřena na využití internetových zdrojů pro výuku angličtiny $\mathrm{v}$ terciární sféře u technického oboru stavebnictví. Studie poukazuje na potenciál internetu pro rozvoj studijní autonomie a zároveň možnost zvládnout značné množství materiálu na internetu. Navrhuje se zde ale též využít technické a vzdělávací možnosti internetu v souladu s potřebami jednotlivých studentů.

Téma genderových rozdílů mezi účastníky elektronického vzdělávání se stává námětem mnoha výzkumů a studií, přičemž rưzní autoři docházejí $\mathrm{v}$ této dynamické 
oblasti k různým závěrům. Naše závěry korespondují se závěry Yukselturka a Buluta (2009), kteří konstatují, že v dřívějších dobách byl internet a počítače převážně mužskou záležitostí, naopak $\mathrm{v}$ současné době studie potvrzují, že prístup $\mathrm{k}$ technologiím a počítačová gramotnost jsou dnes doménou mužů i žen ve stejné míře (Gunn et al., 2003, Ono a Zavodny, 2003, in Yukselturk a Bulut, 2009). Z naší studie vyplynulo, že nulová hypotéza týkající se genderu, zamítnuta nebyla (viz Tabulka 6 a 7). Platí tedy, že ženy a muži dosahují stejných odborných jazykových znalostí z hlediska bodového hodnocení v závěrečných didaktických testech, a že studium prostřednictvím e-learningu je pro ženy stejně úspěšné jako pro muže. Toto tvrzení by mohlo platit obecně, nebot' naše údaje jsou v souladu s existujícími závěry výzkumů, které konstatují, že rozdíly mezi pohlavími jsou zanedbatelné (Astleitner a Steinberg, 2005, Lu et al., 2003, Ory, Bullock a Burnaska, 1997, Sierra a Wang, 2002, in Yukselturk a Bulut, 2009).

\section{Literatura}

Astleitner, H., \& Steinberg, R. (2005). Are there gender differences in web-based learning? An integrated model and related effect sizes. AACE Journal, 13(1), 47-63.

Attwell, G. et. al. (2006). E-learning in Europe - Results and Recommendations (Thematic Monitoring under the LEONARDO DA VINCI-Programme). Bonn/Berlin: Agentur BIBB.

Fernandez-Manjon, B., \& Sancho, P. (2002). Creating cost-effective adaptative educational hypermedia based on markup technologies and e-learning standards. Interactive Educational Multimedia, number 4: 1-11.

Honigsfeld, A., \& Dunn, R. (2003). High school male and female learning-style similarities and differences in diverse nations [Elektronická verze], The Journal of Educational Research, 96(4), 195-207. Dostupné z WWW:

$<$ https://341elmoreinquiry.wikispaces.com/file/view/GenderLearningStylesDiverseNatio ns.pdf $>$.

Gunn, C., McSporran, M., Macleod, H., \& French, S. (2003). Dominant or different?

Gender issues in computer supported learning. Journal of Asynchronous Learning

Networks, 7, 14-30.

Chyung, S. Y. (2007). Invisible Motivation of Online Adult Learners during Contract

Learning. Journal of Educators Online, $v 4 \mathrm{nl}$.

Liu, M., Moore, Z., Graham, L., \& Lee, S. (2003). A look at the research on computerbased technology use in second language learning: A review of the literature from 19902000. Journal of Research on Technology in Education, vol. 34, no. 3, pp.250-273.

Lu, J., Yu, C, S., \& Liu, C. (2003). Learning style, learning patterns and learning performance in a WebCT-based MIS course. Information \& Management, 40, 497-507. Ory, J. C., Bullock, C., \& Burnaska, K. (1997). Gender similarity in the use of and attitudes about ALN in the university setting. Journal of Asynchronous Learning Networks. Price, L. (2006). Gender differences and similarities in online courses: challenging stereotypical views of women. Journal of Computer Assisted Learning, 22, 349-359. Sak, P., \& Saková, J. (2007). Člověk a vzděláváni v informační společnosi, Praha:Portál. Rovai, A. P., \& Baker, J. D. (2005). Gender differences in online learning: Sense of community, perceived learning, and interpersonal interactions. The Quarterly Review of Distance Education, 6 (1), 31-44.

Sierra, C., Wamg, M. (2002). Gender, discourse style, and equal participation in online 
learning. In G. Richards (Ed.), Proceedings of E-Learn 2002 Conference (pp. 23642367), Chesapeake, VA: AACE.

Šimonová, I. (2008). Využivání multimédií při výuce odborné angličtiny na FIM UHK. eLearning: sborník př́spěvkio z konference a soutěže. Hradec Králové: Gaudeamus, s. 8892.

Tallent-Runnels, M. K., Thomas, J. A., Lan, W. Y., Cooper, S., Ahern, T. C., Shaw, S. M., \& Liu, X. (2006). Teaching courses online: A review of the research. Review of Educational Research, 76, 93-135. doi: 10.3102/00346543076001093.

Taplin, M., \& Jegede, O. (2001). Gender differences in factors influencing achievement of distance education students. Open Learning, 16 (2), 133-154.

Warschauer, M. (1995). E-mail for English teaching: Bringing the Internet and computer learning networks into the language classroom. Alexandria, VA: TESOL Publications. Yeung, D. (2002). Toward and effective quality assurance model of web-based learning: The perspective of academic staff. Online Journal of Distance Learning Administration, 5(2). Retrieved July 16, 2002, from State University of West Georgia, Distance Education Center Web site: Dostupné z WWW:

〈http://www.westga.edu/ distance/ojdla/summer52/yeung52.htm> Yukselturk, E., \& Bulut, S. (2009). Gender Differences in Self-Regulated Online Learning Environment. Educational Technology \& Society, 12 (3), 12-22.

Zhao, Y \& K. A. Frank (2003). Factors affecting technology uses in schools an ecological perspective. American Educational Research Journal, Vol. 40, No. 4: 807840.

Zhao, Y., Pugh, K., Sheldon, S., \& Byers, J. (2002). Conditions for Classroom Technology Innovations. Teachers College Record, 104(3 